Kohl: a Journal for Body and Gender Research

Vol. 3, No. 2 (Summer 2017)

\title{
Gender Binaries and Sexual Violence in Adult Comics During Post- Revolutionary Egypt
}

\author{
Sara Shaker
}

\begin{abstract}
:
This article examines whether the male-centric production of adult Egyptian comics in postrevolutionary Egypt challenges and subverts gender stereotypes and the binaries of femininity and masculinity, with a particular focus on two comic magazines, Al Shakmgia and TukTuk. It presents the work of some of Egypt's comic artivists that attempt to fill an analytical gap when it comes to the visualization of women's sexualities, whether in Egyptian adult comics or in media more generally. This article consists of four main sections. The first section elaborates on the importance of studying comics and the considerable obstacles that the circulation and development of comics face inside Egypt. The second section provides a short backgroud about the history of adult comics in Egypt. While the third section explores and revisits the concepts of femininity and masculinity in the comics, the fourth focuses on sexual violence and redefining consent. Finally, the last section addresses the question of the scarcity of women comic artists, highlighting the pervasiveness of hegemonic masculinity, whether materially or in comic representations.
\end{abstract}


In Egypt, storytelling about the everyday is often conditioned by and through the current political climate, particularly after the January 252011 and the June 302013 political turning points. It is thus vital to create and sustain spaces that are able to engage with storytelling and highlight the sexual and gendered imaginaries of Egyptian feminists and activists. As a medium, comics are older than film, television, and video games; yet, there has been resistance from the academic community to examine and analyze them as a coherent medium (Ndalianis 2011:113). Through the "visual conventions" of comics, we "perceive and transmit our understanding of the world around us" (Gilman 1992:223). In comics, visual conventions can be found where the existing social realities is not "presented" but rather "represented." These representations used by comic creators shape our understanding of how we look upon ourselves as well as others. We read comic books with our imagination, bringing about possible re-experiences and reenactments of the world, whether through the eyes of the illustrator or through our own imaginaries. They enable us to visually give meaning to memories, family constructs, kinship, war, death, trauma, joy, laughter, passion, and even zombies. Visual imagery has become one of the effective communication tools to deliver abstract and intangible ideas that could contribute to putting political change into motion.

Through visualization, this article attempts to appeal to the imagination of the illustrators and the readers, challenging the binary of femininity and masculinity. It explores the work of some of Egypt's comic artivists in order to fill an analytical gap in regard to the visualization of women's sexualities in Egyptian adult comics. The presented research challenges the status quo of mainstream representations of gender and sexuality in the Egyptian context, showing political imaginaries and visions that distance themselves through comics from the dominant hegemonic perception of masculinity and rape culture. Nevertheless, it argues that some of these attempts at women's visualization, although well-intentioned, end up ridiculing strong women and feminist demands in the Egyptian media, including comics, therefore reproducing gender stereotypes rather than subverting them. The article relies on both discourse analysis, analysis of visual texts, and interviews with artists and curators in order to explore the comic depictions.

\section{Why Study Comics in Egypt}

Comics continue to claim space in magazines and newspapers where allegories, humor, and satire flourish with no placid representation of static consensus. They are becoming a valuable window into the mentalities and politics of young adults with their transmission and challenge of socially defined norms and their frequent politicization. In the foreword of Joe Sacco's Palestine (2001), Edward Said discusses comics as a vector for rebellious thought via their creative colors and panels (2001:2). Comics are characterized by their contested and eccentric insight into freedom of expression. As Martyn Pedler argues, comics are not exposed to a continuous process of editing and filtering to achieve high sales. Instead, it is within the discretion of the reader to flick across the pages (as cited in Ndalianis, 2011:114). The comic platform functions as a communication channel that brings unspoken issues to the surface. Today, it reflects heated debates around contextual realities in Egypt along with colloquial dialects, exploring taboo issues of women's sexualities. For example, a story titled "The Skin," which appeared in the second issue of TukTuk by the male artist Makhlouf, was the cause of an uproar at one of the branches of Al-Shorouk bookstore. The comic revolves around a man named Ibrahim who 
wants to engage in sexual intercourse with his wife; yet, he does not like the taste of her lipstick. However, the wife insists on wearing this lipstick despite her husband's insistence to feel the texture of her skin. Instead of heeding his friends' advice to kill her, he eventually gives up on his wife, refusing to engage in any sexual behavior with her. He remains married but with a constant fear of this nightmare called the lipstick. Upon browsing through the story, a mother yelled at the management, prompting the bookstore to withdraw all available copies in the market.

Until today, there are still considerable obstacles facing the circulation and development of comics in Egypt, despite the fact that comic magazines are not exposed to any form of censorship from a supervisory or regulatory official body. First, the non-documentation of adult comic magazines and the inaccessibility to resources has made it very difficult to examine different understandings/perceptions of sexuality. It should be noted that across Egyptian libraries and bookstores, there is no section or a newsstand for Egyptian adult-based comics. Thus, it was only through contacting Mohammed El Shennawy, one of the founding members of TukTuk who compiled all the produced adult comics in post-revolutionary Egypt, that this research came to being. Second, the non-contribution of the majority of female comic artists, with the exception of Doaa El Adl and Hadeel Mohammed, makes it very hard to provide the perspectives of other female comic artists, whose voices were silenced by the patriarchal control over women's body and sexuality, whether by the family, state, or religious institutions. Third, except for the work of Jacob Høigilt (2017), and Douglas and Malti-Douglas (1994) on comic strips in the Arab World, there is very limited scholarly discussion of Egyptian comics, which makes providing a precise understanding/explanation of gender sexualities, one of the main challenges in this research.

Nonetheless, some of these obstacles are being addressed through the efforts of Ahmad Al-Huwwari and Mohamed Ismail (Al-Saadi 2013). Al-Huwwari is the main creator of arabcomics.net, a website that consists of an Arab collection of comics. It includes scanned copies of Arab comics, translated foreign comics, and old Miki comics. ${ }^{1}$ As Ahmad Al-Huwwari explains, "our main goal is to return this art form to the people. The new generation isn't aware of the iconic history of comics, the Gold Age, where comics would come out weekly and sell really well" (Al-Saadi 2013:3). Today, there are other initiatives besides the launching of Arabcomics.net, such as Koshk Comics, arab-comics.byethost15.com, Comics4Arabs.com, Comixawy, and thecomicsman.blogspot.com that aim to ensure the survival of an Egyptian comic culture that is historically evident (Al-Saadi 2013). In addition to online platforms, documentaries also pay attention to the importance of comics, such as "Comex BEIMasry (Egyptian Comics)," a documentary that compiles the history of Egyptian comics since ancient Egypt (Unpublished: based on primary research).

\section{Background on Adult Comics in Egypt}

Prior to 2011, Majdi Al-Shafii's graphic novel Metro was considered the first landmark in the development of independent adult comics in the region. The novel discusses Mubarak's unjust regime, with a particular emphasis on the Ministry of Interior. The novel is seen as one of the first contemporary cultural texts that reflect the positions of Egyptians vis-a-vis the miserable living conditions and unequal

\footnotetext{
${ }^{1}$ Miki: Disney Comic Stories that were translated to Arabic by Dar Al-Hilal Publishing House in Egypt, 1959.
} 
opportunities for the youth. Due to its critical posture, the Egyptian authorities detained Muhammad AlSharqawi, the publisher, and Al-Shafii for defying the Egyptian State power. Translated into English, German, and Italian, Metro gained wide appeal in Egypt and abroad, leading to the increasing support for producing adult comics in the region.

During pre-revolutionary Egypt, comics became an expressive tool for many vocal dissidents. For example, in 2008, Tarek Shahin created the online comic strip Al Khan, that ran under the auspices of The Daily News Egypt. Al Khan narrates the return of Omar Shukri, who left his banking job in London and came back to Egypt. ${ }^{2}$ The strip became famous for criticizing the hegemonic discourses of the Egyptian state, which exemplifies the power of a comic in disrupting the dominant political representations of an existing regime (Mitchell 2013). Shahin, the comic illustrator, disputed the stability discourse offered during the Mubarak regime, providing a different visualization of Egypt and its people.

With the outbreak of the 25 January Uprising, the Egyptian literary scene became heavily surrounded with the blossoming of Egyptian adult comics that encompass a wide range of styles, from Japanese manga to bande dessinée. In 2011, the first issue of TukTuk was published. TukTuk is bimonthly, independent comic magazine run by its founding team, Mohammed Shennawy, Mohammed Tawfik, Mokhlouf, and Hicham Rahma. Its title signals the transportation vehicle (i.e. small three-wheel motorbike taxis) used by the majority of Egyptians throughout the streets of Cairo, witnessing the everyday lives of individuals from the smallest alley to the largest avenue in Cairo. It is also an onomatopoeia, symbolizing the echo sound of knocking on doors. To sustain TukTuk's production, the founding members relied on income made from sales rather than depending on donors. With six issues financed by the European Union (EU) Fund, TukTuk founders emphasized that there has been no interference of any kind in their comic art (Interview with the two founding members of TukTuk, Mohammed Tawfik \& Hicham Rahma, 1st June 2015, $5^{\text {th }}$ June 2015 respectively)

Inspired by the success of TukTuk, the feminist organization Nazra for Feminist Studies aimed to disseminate the stories of marginalized groups through a safer space like comics. In 2014, AlShakmgia, an occasional magazine, came to being. When taking charge, Fatma Mansour, the editor in chief, researched the political adult comic magazines in the Egyptian market in order to hire artists with experience in the field, which is why the majority of comic artists and writers working for TukTuk are also employed in Al-Shakmgia. As Mansour explains, Al-Shakmgia (i.e. the jewelry box) is a piece that one finds in all households and across all social classes. Despite receiving support from foreign feminist NGOs, the team completely rejected any imposition or intervention in the production and presentation of their comic art (Interview with Fatma Mansour, Editor in Chief of Al-Shakmgia, 11th June 2015). The online version of Al-Shakmgia is available on Kotobna, an online platform, where the magazine has been one of the most downloaded materials, Mansour asserted. ${ }^{3}$

\footnotetext{
2 Tarek Shahin. Al-Khan Comic: https://alkhancomics.com/

${ }^{3} \mathrm{Al}$-Shakmgia is available through Kotobna via this website link: http://kotobna.net/Book/Details?bookID=17
} 
Comics, as a form of visual art, can be considered a type of activism that can disclose political, social, and cultural issues in an attempt to bring change. On one hand, artists deploy public space to raise political consciousness and to give a voice to those who have been silenced and excluded from political and social engagement. On the other hand, as activists, they occupy public space by virtue of their activist engagement with the political platform. Yet, "To what extent are artists-activists just theorizing their practice as opposed to developing practical hands on activism" and actually bring change, particularly in the area of women's sexualities? (Acevedo-Yates 2013). As De Cauter (2011) argues, art has the ability to create/establish new openings within the confinements of an existing system, thus playing a more pronounced role in the private sphere. The Egyptian feminist art movement has deconstructed the private/public binary since the 1970s, bringing the personal into public space, and articulating women's experiences from both a social and political position. For example, Heba Helmi's art brings in new possibilities for feminist intervention, particularly in Egypt. A visual artist and an activist, Helmi illustrated a series of posters titled El Settat Hatharrar Masr (Women Will Liberate Egypt) of pioneering Egyptian women in different fields of art, science, education, and activism. The posters depict the history of prominent female Egyptian figures, reviving their memory, giving them a voice, and maintaining the link with earlier generations of feminist proponents (as cited in Soliman, 2014:7). But how far is visual art influential/effective in in supporting/promoting the feminist cause? As Mounira Soliman (2014) argues, visual art has the ability to reclaim public space on a wide scale, drawing attention to the continued attempts at marginalizing women in patriarchal systems.

In the comic magazines of TukTuk and Al-Shakmgia, artists actively seek to challenge sexual harassment and its portrayal in mass media production. They also attempt to move beyond the stereotyped visualization of femininity and masculinity and their binary. Their images of women are neither characterized by their large bust sizes, slim figures, bare legs, and half-naked appearances, nor do they represent an idealized form of womanhood. However, the stories sometimes fall short of resisting and subverting normative discourses of femininity, visualizing women's existence in a completely different picture, and accounting for the gendered dimension of violence.

In the story of "Half Way Through," published in Al-Shakmgia in 2015 by the comic illustrator Hicham Rahma and comic writer Mohammed Ismail Amin, women negotiate their self-identities beyond the binary notions of the body as masculine and feminine. The story begins by a broadcast of the funeral of Hamada Ahmed El Tohamy, the last man to survive the spread of the y2h1 virus that exterminated all the men of the world. The broadcast is covered by Safaa Al Mahdy, the President of the Arab Republic of Egypt. Consisting of female characters, such as Olfat, Zeinab, the tuktuk driver, and the female representatives of the Somali delegation, the comic continues with Zeinab driving Olfat in the tuktuk to pick up the Somali delegation from the airport. Once in downtown, the Somali delegation requests that Olfat takes them to Dr. Reem's laboratory (later turned into a museum), where the virus that eradicated men was created and where Dr. Reem committed suicide. "What made her [Dr. Reem] do that?," one of the female Somali representatives asks, to which Olfat responds that Dr. Reem was sexually assaulted and subjected to collective rape, and that her traumatizing experience led her to create the virus. Olfat then takes the Somali delegation to Taalat Harb Square in downtown Cairo, where female street vendors sexually harass them both verbally and physically. Subsequently, one of the Somali women 
resign from her governmental job, vowing to proceed Dr. Reem's work, who only did the job "half way through."

Whether intentionally or not, Rahma's story exonerates the concept of hegemonic masculinity entrenched in our patriarchal societies. The term, coined by the Australian sociologist Raewyn Connell, refers to the qualities different cultures assigned to men and how these traits allow them dominance over women (2005:832). In media culture, hegemonic masculinity is identified through four main features of power, defined as follows: "in terms of physical force and control (particularly in the representation of the body);" "as occupational achievement in an industrial, capitalist society;" as "represented in terms of familial patriarchy;" and "heterosexually defined and centered on the representation of the phallus" (Trujillo 1991:291-292). In other words, hegemonic masculinity reinscribes gender practices that perpetuate the positional dominance of men over women and their socioeconomic superiority. A gendered order is maintained through fixed enactments of masculinity and femininity as a binary from within a hierarchy of structured power relations. Hegemonic masculinity becomes the most desired practice reinforcing demonstrations of heterosexuality, aggression, and assertiveness among men (Connell 2005:848).

At first glance, the portrayal of the female characters "Half Way Through" seems to challenge the notion of fixed femininity by having them exhibit characteristics typically attributed to men, such as physical strength, and adopt jobs traditionally perceived as male, such as diplomats, tuktuk drivers, or doctors. The comic does portray women in positions of power, which offers a welcome break from the widespread portrayal of women in secondary roles in most comics: "Not every woman in comics has been killed, raped, depowered, crippled, turned evil, maimed, tortured, contracted a disease or had other life derailing tragedies befall her, but given the following list.... It's hard to think up exceptions" (Gail Simone as cited in Phillips \& Strobl, 2013: 166). Nevertheless, the comic story takes away the gendered aspect of sexual violence and harassment in some instances. Rahma's post-apocalyptic, post-gender depiction seems to be arguing that men are not the only ones who can be violent towards women, but women could also be the perpetrators of such violence. Turning female street vendors into harassers, particularly in the area of Talaat Harb Square that was known to be the site of collective rapes during the revolution, obscures the material realities of assault, harassment, and violence, and takes away from the political histories and collective memory of violence Egyptian women faced. While Rahma attempted to challenge the binaries of femininities and masculinities, the comic shifted attention from the focus of sexual violence against women, and neither accounted for masculinities that do not fall under hegemonic masculinity, nor examined how masculinity is actualized and reproduced in daily life. As Farha Ghannam $(2013: 24,105)$ argues, "When people think of gender issues in the Middle East, they usually think of women and how women are always oppressed by men. Yet, one can examine how different elements like class intersects with gender; exploring how many men are oppressed whether economically, socially, or politically." Instead, the comic reproduces the notion that class oppression is correlated with higher perpetrators of violence, taking it further by imagining that in the absence of men, masculine-looking women would be taking on that role. In turn, gender fluidity is caricatured, and gender roles remain fixed in a binary, with the difference of the two sides being interchangeable. 


\section{Reclaiming the Body, Redefining Violence}

Even though comics tend to address real life issues, women in comic books are often ascribed passive roles in which they become sexualized objects in need of protection (Robbins n.d). Even if they are represented as unquestionably strong characters in the male-dominated comic industry, the narrative shifts to their categorization as sex symbols with male characters taking advantage of them. Thus, despite their portrayal as strong, they are ultimately victimized (Robbins n.d). Nevertheless, the comic story of "Thistles" 4 in TukTuk (2015) by Reem, an Algerian comic artist and one of the few women to illustrate comics, reclaims the narrative of rape, exposing rape culture in the Arab World. According to Rahma, one of the founding members of TukTuk, Reem, the Algerian comic artist who created this story, met with him and Mohammed Shennawy (main founder of TukTuk) during "FIBDA" (Festival International de la Bande Dessinée d'Alger) in Algeria, the most important event for comics across the Arab world. During this conference, Rahma and Shennawy met a number of Algerian artists including Reem. The encounter led them to publishing her story in issue 7 of TukTuk. "Thistles" challenges the trivialization, normalization, and naturalization of rape and sexual violence by showing rape culture as pervasive. By doing so, she brings the conversation back to consent. Through her drawing techniques, she depicts a sequence of images of sexual violence and assault that do not involve coercion by physical force. The comic illustrator shows tacit forms of violence that are pervasive despite women's strategies of self-protection. Indeed, the story is silent and does not include a single word except for the title. It is interesting to note that the entire attire of the female character is covered in thistles; yet, the difference in size between the small woman and the giant man makes it impossible for her not to be swallowed whole (literally). The man the size of a giant has no face; the reader can only see only hands that uncover specific body parts, like the ass and the boobs, and mouth that devours.

The woman in "Thistles" reveals no apparent emotion; even her facial expressions show a neutral stance. She does not rebel against the hand touching her by biting, spitting, burning, screaming or even crying. But consent is not synonymous to non-reaction or non-resistance, and many instances of sexual violence take place through manipulation and psychological coercion, whether in the public or the private. Hence, such a visualization of the incident challenges the preconceived notions, rife in the Egyptian mainstream imaginary, of how victims and perpetrators are supposed to be acting. The majority of comic magazines or books reinforce misconceptions around what constitutes rape and what does not, ignoring that sexual assault can happen with no overt displays of physical force. Furthermore, most comics visualize rape in a way that places the burden on the woman for allegedly "provoking" someone to rape her, or blaming her for not fighting hard enough to make the perpetrator stop. Thus, many comics unintentionally reiterate the sexist argument that women asked for it. Unlike the unrealistic portrayals of sexual assault in some of the comic books, "Thistles" challenges rape culture in patriarchal societies, as well as misinformed notions around sex and consent. It reaffirms that consent should be explicitly given and can be revoked at any time. Additionally, it deconstructs the sexist assumption that men are "unable" to control their sexual "impulses." Not only is the apologetic exceptionalism that dismisses rape as unrelated incidents perpetrated by those who are "unstable" stigmatizing in terms of

\footnotetext{
4 Excerpts from "Thistles" can be found at the following link: https://blogs.prio.org/2015/04/comics-and-theliberation-from-patriarchyl
} 
mental health, but Reem's story also shows that sexual violence is pervasive, systemic, and can happen in one's own community.

\section{On the Lack of Women Comic Artists}

The goal of TukTuk and Al-Shakmgia, as argued by Mohammed Tawfik, one of the founding members of TukTuk, is not to provide solutions for existing problems like harassment, rape, and other acts of violence; rather, they aim to create a platform where comic artists are able to discuss taboo issues such as sexuality without censorship. Because of their dazzling pictures, Tawfik continues, comics attract the reader, lifting up the burden of reading, which makes of them a powerful tool to disseminate a message. As Chute argues, "the disgust and the pleasure that the visual carries is related to a bodily rhythm of reading, further underscored and prompted by the rhythm of the visual-verbal page, a rupturing alienation between affects" (2010:71). At the same time, unlike Egyptian cinema, there is no supervisory institution that overlooks and censors comic works before publishing it publicly (Interview with the researcher 1 June 2015). Tawfik highlights that comics are becoming a strong platform for women to examine gender-related issues. I interrupt him to point out the contradiction of his claim, as most of the drawings and scripts are created by male artists and writers, whether in TukTuk or AlShakmgia. However, he continues by claiming that there exists no difference between male and female artists depicting women in distress, as he finds no issue with knowing a man's perspective in areas like sexuality through comics.

Hicham Rahma stresses that TukTuk is open for all artists from the Arab world and not only Egyptians. Throughout the issues of the comic magazine, one can find a diverse group of artists from Lebanon, Morocco, and Tunisia. While interviewing Rahma, it was interesting to note how he elaborated on the limited contribution of female artists, as it would change TukTuk's perspectives on a wide range of issues. When I inquired about the limited presence of female artists in TukTuk, he admitted he did not know the reason, but argued that TukTuk's doors are open to anyone to join, whether women or men. For instance, while discussing the issue of sexual harassment with him, he explained that as an Egyptian man, he can walk in the streets wearing shorts and no one would dare to say a word. That is why he believes if such an experience was to be projected in a comic, it would better portrayed and narrated from the point of view of the female artist, as women have firsthand experience of being caged and under scrutiny while walking on the streets. For Rahma, comics give a chance for the other to actually speak for themselves. The aesthetic and coercive nature of rape, when narrated visually, make it possible to the reader to interact with its complexity (Tolmie, "Introduction," 2013). Yet, when looking for women comic artists, Fatma Mansour, Mohammed Shennawy, and Hicham Rahma explain that it was like looking for a needle in a haystack. According to Mansour, women comic artists are hard to find because it involves improvisation outside of conventional narratives, and women are still shy in expressing themselves compared to men because of societal pressure that places them in specific gender roles. The limited number of women artists in the comic field is also attributed to the fact that, unlike men, they are not able to stay out late to market their comics (based on interviews). Any employer in the comic industry is thus hesitant to employ a woman for fear that her family would restrict her time. At the same time, it is very rare to find a woman artist graduating with a specialization of comics, particularly in Egypt. 
Therefore, claims like Mohammed Tawfik's unintentionally reinforce men's hegemony over women and fortify social inequalities that put women at a disadvantage. Stressing on the "two-sided perspectives" comics have the room to elaborate on obscures that the sides are not equal and do not possess the same means of artistic creation and production, specifically because minority groups like women are not afforded the same social opportunities.

When I interviewed Fatma Mansour, she noted that Hicham Rahma and Mohammed Ismail Amin, the comic creators of "Half Way Through," were not convinced with the way it was produced. Rahma had informed me that the script had been sent to him first by the writer, and this was how he imagined to present the story, with no particular message to send to the reader. He asserted that unlike caricature, which usually has an implicit message through its illustrations, comics are more based on narration through which artists are able to project their own opinions. Mansour, on the other hand, attributes it to a limited knowledge of gender-related issues. She highlights that illustrators are not feminists; yet, through their comic art, they are able to find a common ground to connect with the wider audience and the broader gender community. For instance, she pinpoints how she organized a feminist orientation session under the auspices of Nazra for comic artists and writers, explaining concepts like gender, feminism, masculinity, femininity, and patriarchy among others. With Mansour arguing that the core theme of "Half Way Through" was to focus on sexual harassment, one cannot escape Hicham Rahma's attempts to move beyond the binary conceptions of masculinity and femininity in the comic panels, although these have led to a dilution of gender violence in some instances (Interview with the researcher $5^{\text {th }}$ June 2015).

This article reveals that the male-centric production of activist comic magazines in Egypt tries to distance itself from a hyper-masculine character presentation of men, and a hyper-sexualized presentation of females performing acts of sexuality. It also attempts to make the means of comic production inclusive of women, but overlooks hegemonic masculinities that are actualized and reproduced in everyday life. While women comic artists are almost non-existent in the Egyptian comic sphere, Reem's "Thistles" was able to break that hegemony, whether materially, or in relation to sexual violence in the story. Reem was able to represent the horror of assault with no single word, capturing its aggression, brutality, and inhumanity. What both "Half Way Through" and "Thistles" brought us, however, is the notion that women do not need to adhere to societal standards of beauty or certain social classes to be subjected to harassment, nor should they be produced and represented as victims, relegated to a second plane in their own stories. 


\section{References}

Acevedo-Yates, Carla (June 27, 2013). "Considering Activist Art in the Age of Occupations." ArtPulse. Accessed from http://artpulsemagazine.com/considering-activist-art-in-the-age-of-occupations

Al-Saadi, Yazan (April 1st, 2013). "Arab Comics: Creating Communities, Archiving History." Al-Akhbar. Accessed from http://english.al-akhbar.com/content/arab-comics-creating-communitiesarchiving-history

Chute, Hillary L. (2010). Graphic Women: Life Narrative and Contemporary Comics. New York: Columbia UP. Print.

Connell, Raewyn \& Messerschmidt, James (2005). "Hegemonic Masculinity: Rethinking the Concept." Gender Society 19, pp.829-859. DOI: 10.1177/0891243205278639

De Cauter, Lieven, De Roo, Ruben \& Vanhaesebrouck, Karel (2011). Art and Activism in the Age of Globalization. Rotterdam: Nai Utigevers/Publishers Stichting. Print.

Douglas, Allen \& Malti-Douglas, Fedwa (1994). Arab Comic Strips: Politics of an Emerging Mass Culture. Indiana University Press: Bloomington and Indianapolis. Print.

Gilman, Sander L. (1992). "Black Bodies, White Bodies: Toward an Iconography of Female Sexuality in Late Nineteenth Century Art, Medicine, and Literature." In Henry Louis Gates Jr. (ed.), "Race," Writing, and Difference. Chicago: University of Chicago Press. Print.

Ghannam, Farha (2013). Live and Die Like a Man: Gender Dynamics in Urban Egypt. Stanford University Press. Print.

Høigilt, Jacob (2017). "Egyptian Comics and the Challenge of Patriarchal Authoritarianism." International Journal of Middle East Studies 49 (1), pp.111-131.

Mitchell, Laura T. (2013). "The People Want The Regime Brought Down': Popular Geopolitics and The 2011 Egyptian Revolution." Master thesis, Durham University. Accessed from Durham eTheses: http://etheses.dur.ac.uk/7280

Ndalianis, Angela (2011). "Why Comics Studies?" Cinema Journal 50 (3), pp.113-122.

Phillips, Nickie \& Strobl, Staci (2013). Comic Book Crime: Truth, Justice, and the American Way. New York: NYU Press. Print.

Robbins, Trina (n.d). "Women in Comics: An Introductory Guide." NACAE: National Association of Comics Art Educators. Accessed from https://www.cartoonstudies.org/wpcontent/uploads/2014/06/women.pdf

Soliman, Mounira (2014). "Between Art and Activism: Egyptian Women and the Revolution." The Singapore Middle East Papers (SMEP) 12 (3), pp. 1-12. Accessed from https://mei.nus.edu.sg/themes/site_themes/agile_records/images/uploads/SMEP_12-

3_Soliman.pdf

Tolmie, Jane (2013). Drawing from Life: Memory and Subjectivity in Comic Art. Univ. Press of Mississippi. Print.

Trujillo, N., (1991). "Hegemonic Masculinity on the Mound: Media Representations of Nolan Ryan and American Sports Culture." Critical Studies in Mass Communication, 8, pp. 290-308.

\section{Comics}

Al-Shakmgia Magazine [Printed Format]. 
Arab Comics. Accessed from http://www.arabcomics.net/phpbb3/portal.php

Comics Man. Accessed from http://thecomicsman.blogspot.com.eg/

Comixawy Comics. Accessed from http://www.facebook.com/comixawy.comics

Koshk Comics. Accessed from https://www.koshkcomics.org/public/start

Majdi Al-Shafii (2008). Metro. Malameh publishing house [Printed Format]

Tarek Shahin. Al-Khan Comic. Accessed from http://alkhancomics.com/

TukTuk Magazine [Printed Format].

Sacco, J., \& Said, E.W. (2001). Palestine.

\section{Documentaries}

Mazg (Producer) \& Mohammed, Ismail (Director).(2013). Comex BelMasry. Egypt (Unpublished). 